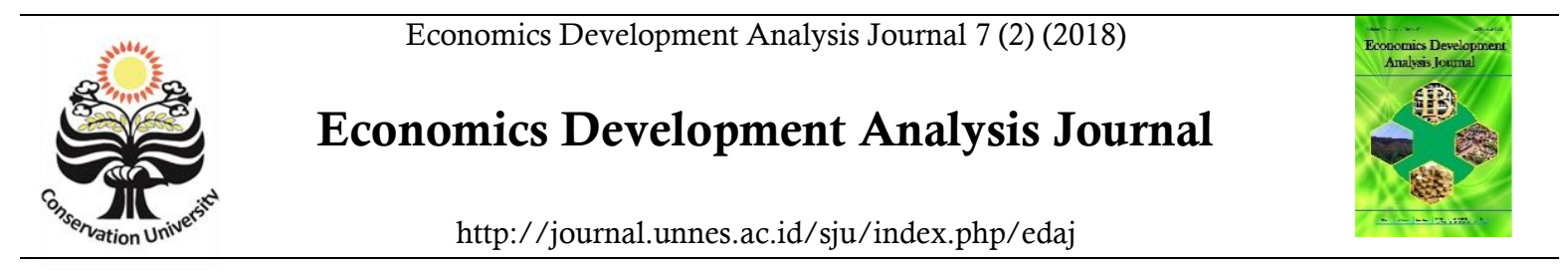

\title{
Analysis of Development Inequality in Kedungsepur Area
}

\author{
Khoir Akfini Didia ${ }^{\circledR}$
}

Economics Development Department, Economics Faculty, Universitas Negeri Semarang

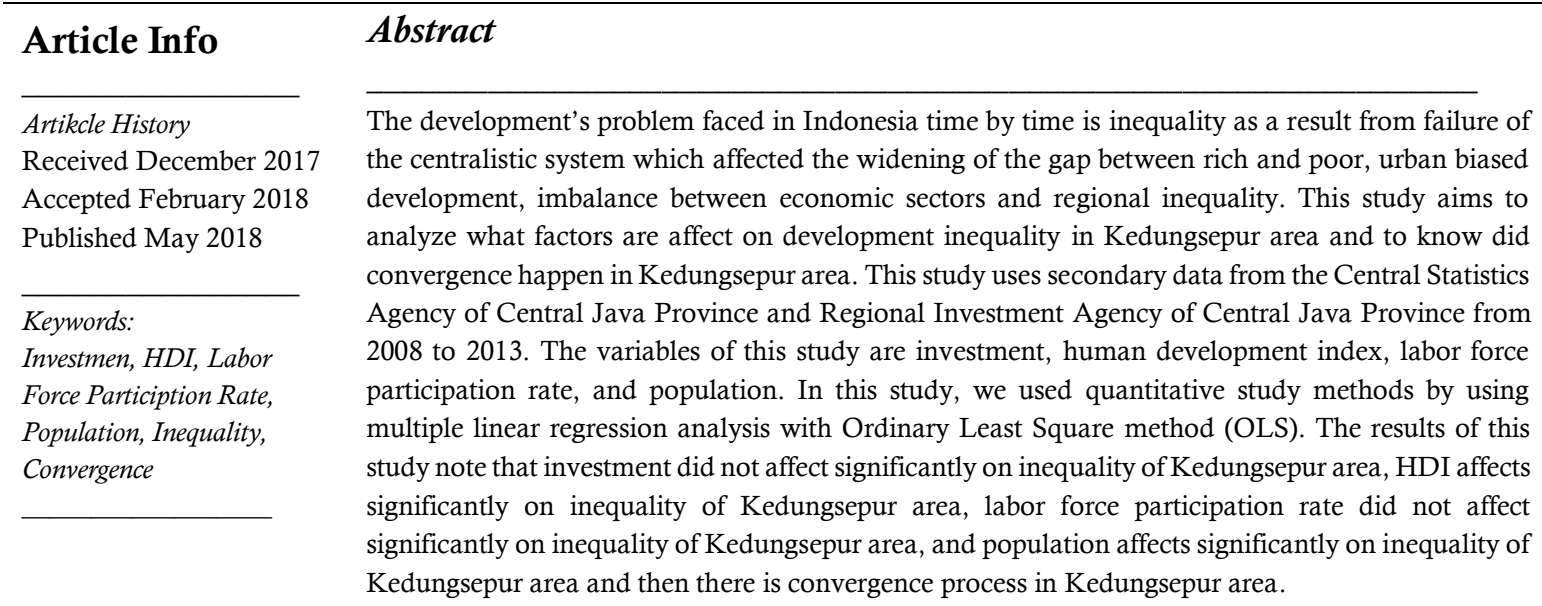

(C) 2018 Universitas Negeri Semarang

\footnotetext{
${ }^{\square}$ Corresponding Author:

Journal Room, Building L2, FE UNNES, Sekaran Campus,

Gunungpati, Semarang 50229, Indonesia

E-mail: kinanvegazra@gmail.com
} 


\section{INTRODUCING}

Poor region or country income would grow faster than rich region or country income therefore on further would reached convergence of income level between region or country concerned, in other words the income in all region or country finally would be on the same level. Pritchett $(1996,1997)$ stated that what happened in world economic growth history virtually is massive divergence between rich and poor country. Fast economic growth ain't result over poor position but that is the result of a series of policies created for facilitating faster growth, thus what important to do and concern about is speed economic growth up through development policies. These policies should support acceleration economic growth which lead to convergence. Therefore the government has big role on giving various forms of supporting for increasing income per capita growth in underdeveloped or poor region.

Regional development process leads to economic growth enhancement and equity optimalitation. Indicator can be used to know how success a given region is is its enhanced of econoomic growth. Therefore government always fix growth rate target in its planning and goals development.

To increase economic growth and region development equity, government of Central Java Province conducted regional cooperation areas which useful in development equity in a given area. According to the provincial regulation of Central Java No.21 2003 about Spatial Plan of Central Java Province, lies in the sixth section stated The Development of Strategic and Priority Areas.

Strategic Development Area is the development area which has productive resources to be developed both in regional or national extent, regional agglomeration, strategic position, and has impact in national and regional development. Area in this concept is space which have geographic entity integrated with concerned factors, where that constrained system is not decided by base of administration and can be divided to some regional functions. Strategic
Development Area also including growth area and potential border which have varying growth acceleration thus can be developed effectively (Kuncoro, 2004).

At the beginning of development all regions have same income per capita pattern, in other words, its development pattern tends to keep rose up, nevertheless after years carry on turns out inequality still happened across region due to each difference on creating economic growth. Over those some areas, Kedungsepur is the area that has highest level of inequality. Even that area include to area which has second highest of Gross Regional Domestic Product from eight strategic areas after Wanarakuti. The development inequality in Kedungsepur can be known from Williamson Index calculation data value as follows.

Table 1. Williamson Index of Strategic Area

\begin{tabular}{lllllll}
\multicolumn{7}{c}{ Central Java Province } \\
\hline Area & 20 & 20 & 20 & 20 & 20 & 20 \\
& 08 & 09 & 10 & 11 & 12 & 13 \\
\hline Kedungsepur & 0.7 & 0.7 & 0.7 & 0.7 & 0.7 & 0.7 \\
& 5 & 6 & 4 & 4 & 5 & 5 \\
Wanarakuti & 0.6 & 0.6 & 0.6 & 0.6 & 0.6 & 0.6 \\
& 8 & 8 & 8 & 8 & 7 & 7 \\
Subosukawono & 0.3 & 0.3 & 0.3 & 0.3 & 0.3 & 0.3 \\
sraten & 4 & 4 & 6 & 6 & 6 & 6 \\
Bregasmalang & 0.2 & 0.2 & 0.2 & 0.2 & 0.2 & 0.2 \\
& 3 & 4 & 2 & 2 & 2 & 1 \\
Petanglong & 0.3 & 0.3 & 0.3 & 0.3 & 0.3 & 0.3 \\
& 1 & 2 & 2 & 2 & 2 & 2 \\
Barlingmascak & 0.5 & 0.5 & 0.5 & 0.5 & 0.5 & 0.5 \\
ep & 7 & 7 & 7 & 7 & 7 & 7 \\
Purwomanggu & 0.3 & 0.3 & 0.3 & 0.3 & 0.3 & 0.3 \\
ng & 0 & 0 & 4 & 5 & 5 & 5 \\
Banglor & 0.2 & 0.2 & 0.2 & 0.2 & 0.2 & 0.2 \\
& 3 & 2 & 0 & 1 & 1 & 1 \\
\hline
\end{tabular}

Source: Central Java Statistic Agency (processed)

Based on Williamson Index strategic area of Central Java Province above provide the highest inequality is on Kedungsepur area explained with WI about 0,75 in 2008, next the second is Wanarakuti explained with WI about 0,68 , while the lowest inequality is on Banglor explained with WI about 0,27 . Inequality in Kedungsepur area had declined in 2010, nevertheless furthermore it keep rising up till 
2013. Inversely proportional to Wanarakuti which inequality had risen in 2010 but continued to decline in the following years till 2013. Williamson Index Table also provide that until 2013 turns out inequality in Kedungsepur still on high position even the government constructed development of strategic area is to reduce inequality as a solution. Inequality in Kedungsepur Area also can be seen from HDI data below:

Table 2. Human Development Index (HDI) each Regencies/Municipalities in Kedungsepur in 2008-2013

\begin{tabular}{lccccccc}
\hline Reg/Mun & 2008 & 2009 & 2010 & 2011 & 2012 & 2013 & Ave \\
\hline Kendal & 69.4 & 70.1 & 70.4 & 70.9 & 71.5 & 72.0 & 70.7 \\
Demak & 71.6 & 72.1 & 72.6 & 73.1 & 73.5 & 73.9 & 72.8 \\
Kab & 73.3 & 73.7 & 74.1 & 74.5 & 75.0 & 75.5 & 74.3 \\
Semarang & 76.5 & 76.9 & 77.1 & 77.4 & 78.0 & 78.5 & 77.4 \\
Semarang & 75.8 & 76.1 & 76.5 & 76.8 & 77.1 & 77.5 & 76.6 \\
Salatiga & 70.2 & 70.6 & 70.8 & 71.3 & 71.8 & 72.4 & 71.1 \\
Grobogan & 70.6 &
\end{tabular}

Source: Central Java Statistic Agency (processed)

Based on Table 2 it provides that Semarang Municipality is area that has the highest HDI while the lowest is Kendal. This identifies that there is development inequality in Kedungsepur Area. Semarang Municipality itself is administrative area as Capital of the Central Java Province, therefore in terms of its developing area Semarang Municipality is the most developed city rather than other regencies in Kedungsepur area. The difference of development can be seen from public services, advanced infrastructure development, high level of education so that provide competent human resources and capital stock also it provided another factors of production. According to Fitriyah and Amin Pujiati (2016) the highest inequality in Kedungsepur area occurs in Semarang Municipality with Williamson Index about 0,61 . This appropriate to Neo Marxist Theory that stated economic growth will always increasing the gaps.

Cooperation effort through strategic area construction, government of Central Java
Province also regard to characteristic similarity on each Regencies/Municipal to be able to work better together and constructed synergicity so the concerned areas can make a reciprocal relation each other in needs and advantages in a single area, furthermore it is expected income equity could occured. Nevertheless the reality is inequality still occurs in Kedungsepur Area.

\section{RESEARCH METHOD}

This research is quantitative research sourced from secondary data. Data used in this research is secondary data sourced at Statistic Agency and Regional Investment Agency reported 2008 until 2013. The data under study include investment data, HDI, Labor Force Participation Rate, Population, and GDRP per capita. Data used in this research is panel data combination of cross section and time series data. This research use two types of variables, they are dependent variable and independent variable. Dependent variables in this research are inequality and GDRP per capita growth, while the independent variables are investment, HDI, Labor Force Participation Rate and Population. Data collection method used documentation method. To know ho much influence independent variable in dependen variable will be analyzed using multiple linear regression model with OLS method (Ordinary Least Square).

\section{RESULTS AND DISCUSSION}

Regression model about the influence of investment, HDI, Labor Force Participation Rate and Population to inequality extent in Kedungsepur Area use multiple linear regression method, Ordinary Least Square (OLS) method. Equation of multiple linear regression model can be seen as follows:

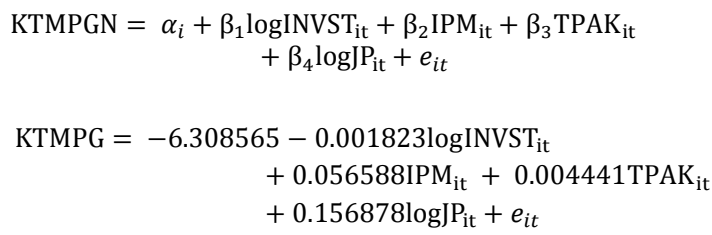


Table 3. Result of Analysis of Multiple Linear Regression Ordinary Least Square Method

\begin{tabular}{lllll}
\hline Variable & Coef & $\begin{array}{c}\text { Std. } \\
\text { Error }\end{array}$ & $\begin{array}{c}\text { Probabili } \\
\text { ty }\end{array}$ & $\begin{array}{c}\text { R- } \\
\text { Square } \\
\text { d }\end{array}$ \\
\hline C & - & 0.6694 & 0.0000 & \\
& 6.3085 & 05 & & \\
LOG(INVS & 65 & & & \\
T) & 0.0018 & 25 & & \\
& 23 & & & \\
IPM & 0.0565 & 0.0054 & 0.0000 & 0.8345 \\
& 88 & 90 & & 67 \\
TPAK & 0.0044 & 0.0040 & 0.2862 & \\
LOG(JP) & 41 & 92 & & \\
& 0.1568 & 0.0231 & 0.0000 & \\
\hline
\end{tabular}

The value of constant or intercept which statistically significant and negative, provide if the other variables in model assumed to be zero, therefore inequality in Kedungsepur Area is about $-6,30$ percent. That negative value of constant indicates this area is not able to resolve the existing problems, proven with there is inequality in Kedungsepur Area in 2008-2013 about 0,75 . It means high inequality occurs in Kedungsepur Area.

Based on analysis regression result can be seen that investment has no directly significant influence to inequality in Kedungsepur Area with coefficient $-0,001823$. Within this terms shows that government role in triggering growth of investment in underdeveloped regions still need to be regarded further can encourage economic growth so that can reduce the gaps. This is not appropriate to Tambunan findings which stated there is positive influence between investment and development inequality. Nevertheless, this research appropriate to Yuki Angelia (2010) result which stated that investment and inequality are negatively associated, more investment used for goods and services production process, where labor can be absorbed more so that income per capita equity could occured (Sadono Sukirno, 1985).

Based on regression analysis result can be seen that HDI variable affected positively and significant with coefficient 0,056588 to inequality in Kedungsepur Area. This demonstrated that if HDI enhanced about $1 \%$, so it can increase development inequality about 0,056588\%. During 2008-2013 periods, Kedungsepur Area belongs to medium level within human development though. It means that Kedungsepur began to regard its human resources development. Nevertheless, positive regression coefficient means that enhancement of HDI makes enhancement in development inequality in Kedungsepur Area. This is possible if the regions which have HDI enhancement are the regions which have had high level in HDI, furthermore it makes widening in difference within resident and causes more development inequality.

In 2008-2013 periods, the highest HDI level is owned by Semarang Municipality, according to Linda Tustiana (2013) based on Location Question, Shift Share, Klasen Tipology, and Scalogram analysis, Semarang Municipality growth characteristic pattern belongs to developed region and fast developed so its development can run better with amenities in a greater degree. Eventhough the other region in Kedungsepur Area also keep risen up on HDI, but the region owned better HDI before, keep risen up either. This research appropriate to Tambunan findings and also support the research Herwin Mopangga (2011) carries out which stated that HDI positively associated with development inequality.

Based on regression analysis result can be seen that Labor Force Participation Rate variable positively associated but not significantly influential to alpha $5 \%$ with coefficient about 0,004441 to inequality in Kedungsepur Area. This demonstrated that if Labor Force Participation Rate 1\% enhanced, it will increase the gaps about $0,004441 \%$. This appropriate to Sjafrizal findings that stated due to migration is less run well, induced labor surplus a single region can not be utilized by other regions who need it. As a result development inequality across regions will tend to be high due to advantages of an area can not be utilized by other regions who need it, so underdeveloped area is hard to push its development process.

Based on regression analysis result can be seen that population variable is positively 
associated and significant with coefficient about 0,156878 to inequality in Kedungsepur Area. This demonstrated that if population enhanced about $1 \%$, further will increase the inequality about 0,156878. This is appropriate to Tambunan findings who stated population structure will affect inequality across regions. This result also support Nurlaili (2016) findings where population positively associated and significant to development inequality. Population can be a factor which enhance inequality if population distribution is uneven. Its uneven population distribution who live a given area will contribute to affect the economic conditions in that area.

Estudillo (1997) explained that income distribution is combination of urban-rural income society, where in common urban income society is greater due to various of people activities in urban area. The enhancement of population in urban area will make income distribution more greater. Aside from that, enhancement of population who skilled and educated that migrate to urban area makes rural area lack of reliable human resources who expected to be able to develope rural economics.

Based on sigma convergence calculation can be concluded that sigma convergence process has been occured in Kedungsepur Area denoted by dispersion from income per capita growth which more declined. This is appropriate to Neoklasik theory which stated that each region or area move towards convergence one level given economic growth due to there is a balance of mastery of production factors across region.

Sigma convergence also indicate that regencies/municipalities in Kedungsepur Area experienced positive economic growth. Aside from it, sigma convergence also stated that to reduce the gaps can not be done quickly and need a long term of process, therefore, it is necessary to develope thorough of the rest of regencies/municipalities to increase economic growth and reduce inequality like transportation infrastructure development, education, agriculture, health as is done by America Serikat and Japan that infrastructure developing (public capital) has big influence for increasing output per capita on the rest of province over the both countries (Shaoji, 2001).

Based on absolute convergence calculation can be conclude that there is no absolute convergence process across Kedungsepur area for 2008-2013 periods. This is demonstrated by coefficient parameter value of initial income per capita which has positive sign, or has a value greater than one.

Based on conditional convergence calculation can be concluded there is conditional convergence process across Kedungsepur area for 2008-2013 periods. This is demonstrated by coefficient parameter value initial income per capita is smaller than one. Convergence speed of income per capita is about 0,066271 which indicate that regencies/municipalities income per capita particularly the region which has low income should grow at least $6,63 \%$ once a year so that the economics will comes to steady state.

There is no absolute convergence across Kedungsepur Area but there is conditional convergence across region in Kedungsepur Area. This support Pritchett hypothesis and Endogenous Growth Theory which stated that fast economic growth ain't the result of poverty but the result over a series of policies created for facilitating rapid growth.

To cover half the income per capita inequality that happened, it takes 10,41 years. Furthermore, to cover all over income per capita inequality, it takes 20,82 years with provided that income per capita should increase at least $6,63 \%$ for each years.

\section{CONCLUSION}

Investment is negatively associated but not significantly influential to inequality in Kedungsepur Area. Human Development Index (HDI) positively associated and significant to inequality in Kedungsepur Area. Labor Force Participation Rate positively associated but not significantly influential to inequality in Kedungsepur Area. Population positively influential and significant to inequality in Kedungsepur Area. 
There is sigma convergence process in Kedungsepur Area with dispersion value from 2008 to 2013 which declined significantly. It means that in aggregate Kedungsepur Area have experienced a process of narrowing the gap.

\section{REFERENCES}

Ajija, Shochrul R,dkk. 2011. Cara Cerdas Menguasai Eviews. Jakarta: Salemba Empat.

Angelia, Yuki. 2010. "Analisis Ketimpangan Pembangunan Wilayah di Provinsi DKI Jakarta Tahun 1995-2008". Skripsi. Fakultas Ekonomi. Universitas Diponegoro.

Arifin, Zaenal. 2009. "Kesenjangan dan Konvergensi Ekonomi Antar Kabupaten Pada Empat Koridor di Propinsi Jawa Timur". Humanity.Hal.154-164.

Arsyad, Lincolin. 2004. Ekonomi Pembangunan. Yogyakarta: STIE-YKPN.

2010. Ekonomi Pembangunan, Edisi ke-5, Yogyakarta: Unit Penerbit dan Percetakan STIM YKPN

Badan Pusat Statistik (BPS). Jawa Tengah Dalam Angka. Tahun 2008-2013.

Barro, Robert J and Xavier Sala-i-Martin. 1995. "Economic Growth". New York : Mc Graw Hill Inc.

Bhinadi, Ardito. 2003. Disparitas Pertumbuhan Ekonomi Jawa dengan Luar Jawa. Jurnal Ekonomi Pembangunan. Vol 8(1).

Emilia dan Imelia. 2006. Modul Ekonomi Regional. Fakultas Ekonomi Universitas Jambi.

Estudillo, Jonna P. 1997. "Income Inequality in The Philippines, 1961-1991". The Developing Economies. Vol 35(1).

Fitria, E. 2006.Analisis Kesenjangan Pendapatan antar Kabupaten/Kota di Pulau Jawa [Skripsi].Bogor : Institut Pertanian Bogor.

Fitriyah dan Amin Pujiati. 2016. "Determinant of Economics Growth in Kedungsepur Region". Economics Development Analysis Journal.Vol $5(2)$.

Fitriyah, Lailatul dan Lucky Rachmawati. 2012. "Analisis Ketimpangan Pembangunan Daerah serta Hubungannya dengan Kesejahteraan Masyarakat di Kawasan Gerbangkertosusila Provinsi Jawa Timur". Jurnal Fakultas Ekonomi. UNESA. Surabaya.

Gujarati, Damodar N. 2010. Dasar-dasar Ekonometrika. Jakarta: Salemba Empat.

Hartono, Budiantoro. 2008. "Analisis Ketimpangan Pembangunan Ekonomi di Provinsi Jawa
Tengah". Tesis.Pascasarjana Universitas Diponegoro Semarang.

Komang Ayuk Pebriani dan I Wayan Sukadana. 2013. "Konvergensi Pendapatan Per Kapita : Studi Kasus Antar Kabupaten di Indonesia pada Era Otonomi Daerah". E-Jurnal Ekonomi Pembangunan Universitas Udayana.

Kuncoro, Mudrajad, Ph.D. 2004. Otonomi dan Pembangunan Daerah Reformasi, Perencanaan dan Peluang.Erlangga.

2006. Ekonomi

Pembangunan: Teori, Masalah, dan Kebijakan. Yogyakarta, UPP STIM YKPN.

Mankiw, N. G. 2003. Teori Makroekonomi Edisi Kelima. Terjemahan. Penerbit Erlangga. Jakarta.

Mopangga, Herwin. 2011. "Analisis Ketimpangan Pembangunan dan Pertumbuhan Ekonomi di Provinsi Gorontalo". Trikonomika.Vol 10(1).

Nurlaili, Ani. 2016. "Analisis Faktor-Faktor yang Mempengaruhi Ketimpangan Distribusi Pendapatan di Pulau Jawa Tahun 2007-2013". Skripsi. Fakultas Ekonomi. Universitas Negeri Yogyakarta.

Peraturan daerah (PERDA) Provinsi Jawa Tengah No.21 Tahun 2003 tentang Rencana Tata Ruang Wilayah Provinsi Jawa Tengah.

Pritchett, L., Forget Convergence: Divergence Past, Present, and Future(http://worldbank.org/fandd/english/ 0696/articles/090696.htm), 1996.

Puspitawati, Linda Tustiana. 2013. "Analisis Perbandingan Faktor-Faktor Penyebab Ketimpangan Pembangunan Antar Kabupaten/Kota di Kawasan Kedungsapur". Economics Development Analysis Journal.Vol 2(2).

Rahman, Yozi Aulia. 2012. "Pengaruh Pengeluaran Investasi Pemerintah Daerah dan Investasi Swasta Terhadap Pertumbuhan PDRB Per Kapita di Indonesia". Tesis.Magister Sains dan Doktor Universitas Gadjah Mada.

Sjafrizal. 2008. Ekonomi Regional Teori dan Aplikasi. Padang-Sumatera Barat: Baduose Media.

Sufii, S. 2008. Konvergensi Ekonomi Regional di Indonesia Tahun 1985-2006.Thesis. Fakultas Ekonomi. Program Magister Perencanaan dan Kebijakan Publik.Universitas Indonesia. Jakarta.

Sugiyono. 2012. Statistika untuk Penelitian. Bandung: Alfabeta.

Tajerin, Akhmad Fauzi, Bambang Juanda, dan Lucky Adrianto. 2013. "Tendensi Proses Konvergensi 
dan Penentu Pertumbuhan Ekonomi Wilayah Pulau Utama di Indonesia". J. Sosek KP Vol. 8 No. 2.

Tambunan, T. 2001. Perekonomian Indonesia: Teori dan Temuan Empiris. Jakarta: Penerbit PT. Ghalia Indonesia.

Todaro, M. dan S. Smith. 2006. Pembangunan Ekonomi. Ed ke-9. Jakarta: Erlangga.

Todaro, P Michael.2003. Pembangunan Ekonomi di Du $\neg$ nia Ketiga. Jakarta: Erlangga. . 2006. Pembangunan Ekonomi di Dunia Ketiga. Jakarta: Erlangga.

Wahyuni, I.G.A.P., Sukarsa, M., Yuliarmi, N. 2014.Pengaruh Pengeluaran Pemerintah dan Investasi terhadap Pertumbuhan Ekonomi dan Kesenjangan Pendapatan Kabupaten/Kota di
Provinsi Bali.E-Jurnal Ekonomi dan Bisnis. Bali: Universitas Udayana.

Widiyati, Sri. 2011. Pengembangan Ekonomi Kabupaten Semarang Melalui Wilayah Andalan.Vol.7 No.1. Hal 1-5. Semarang: POLINES.

Wibisono, Yusuf. 2003. Determinan Pertumbuhan Ekonomi Regional: Studi Empiris Antar Propinsi di Indonesia, Jurnal Ekonomi dan Pembangunan 52-83.

Wiyati, R.B. 2004. Analisis Konvergensi Pembangunan Antardaerah (Studi Kasus: Percepatan Pemerataan Pembangunan di Jawa Tengah 1993-2000). Jakarta: Program Pascasarjana Universitas Indonesia. 